\title{
The Growth and Development of Winter Wheat in the Conditions of Lead and Oil Pollution
}

\author{
Sergey I. Kolesnikov ${ }^{1 *}$, Maria G. Zharkova ${ }^{1}$, Kamil Sh. Kazeev ${ }^{1}$, Tatyana V. Denisova ${ }^{1}$, Yuliya V. \\ Akimenko ${ }^{1}$ \\ ${ }^{1}$ Academy of Biology and Biotechnology, Stachki ave., 194/1, Rostov-on-Don, 344090, Russia \\ *Corresponding author E-mail: kolesnikov@sfedu.ru
}

\begin{abstract}
Exceeding the background lead content in ordinary chernozem by $25 \mathrm{mg} / \mathrm{kg}$, and the oil content of $0.25 \%$ of soil weight, cannot be considered environmentally safe. These doses cause significant impairment of growth and development of winter wheat. Moreover, lead enters grain and straw in large amounts.
\end{abstract}

\section{Introduction}

Numerous studies have shown the negative effect of heavy metals, particularly lead, oil and oil products on plants [1-8]. The main reasons for slow development of plants or their destruction due to contamination with oil are disorders in penetration of water and nutrients alongside with oxygen starvation, and in the case of heavy metal pollution - a metabolic disorder due to the deterioration of the permeability of cell membranes and inhibition of enzyme activity. The majority of studies were conducted in vegetative pots.

The present study is the first one studying the effect of lead contamination of ordinary chernozem with oil on the growth and development of winter wheat in the field model experiments.

\section{Objects and Methods of Research}

Field model experiments were carried out on ordinary chernozem (severopriazovsky) in the Botanical Garden of the Southern Federal University (Rostov-on-Don city). The width of chernozem humus horizon is about $80 \mathrm{~cm}$, the granilometric composition is hard-loamy soil, the medium reaction is 7.7 , humus content is $4.1 \%$, total nitrogen (by Kjeldahl) is $0.25 \%$; total phosphorus (by Ginzburg et al.) is 0.18 ; mobile phosphorus (by Machigin) is 28.8 and total kalium (by Berzelius) is $2.06 \%$.

We used the plot areas of 1 square meter and spacing of $0.5 \mathrm{~m}$ between the plots. The replication was triple.

Lead was introduced in the soil in different doses - 25, 50, 100, 250,500 and $1000 \mathrm{mg} / \mathrm{kg}$. Background lead content in soil was $15.3 \mathrm{mg} / \mathrm{kg}$. Maximum permissible concentration (MPC) of lead in soil is $32 \mathrm{mg} / \mathrm{kg}$ in Russia[8]. Lead oxide (II) $\mathrm{PbO}$ was used. Soil contamination with lead in $70-90 \%$ occurs in the form of oxides [9].

Oil was added to the soil at doses of $0.25 ; 0.5 ; 1,0 ; 2.5 ; 5,0 ; 10.0 \%$ of soil weight. Oil MPC in the soil has not been determined yet.
The oil used in this study was characterized by average density of $(0.8616 \mathrm{~kg} / \mathrm{M} 3)$, average sulfur content of $(1.34 \%)$ and chloride salts content of $(73.0 \mathrm{mg} / \mathrm{dm} 3)$, low-solids content of $(0.0060 \%)$, and wax mass fraction content of $-4.46 \%$.

Since lead oxide is insoluble in water, for uniform distribution in the soil it was first triturated with small amount of soil in a mortar, and then mixed with a large amount of soil in the basin, and then maximally evenly distributed in the upper layer of soil plots (0-20 $\mathrm{cm})$ by digging. Oil was added above ground using method of sprinkling.

Experimental plots were laid in August. In a month they were planted with winter wheat (Donchanka type).

Indicators of winter wheat condition were determined in May next year.

In order to verify the accuracy of the obtained data the analysis of variance was performed followed by determination of the least significant difference (LSD) [10].

Computer program Statistica 6.0 has been used for mathematical processing of results of the study.

\section{Result and Discussion}

Contamination of soil, even with significant amounts of lead (background $+1000 \mathrm{mg} / \mathrm{kg}$ ) had no practical effect on the morphometric indicators of the vegetative organs of winter wheat (see Table 1). Moreover, statistically insignificant increase of indicators was generally observed at doses of contamination (background $+25,50,100$ ). At the same time, indicators of the generative organs, including yield, reduced their value down to 3 times. 
Table 1: Influence of ordinary chernozem pollution with lead on growth and development of winter wheat (Botanical Garden of SFU)

\begin{tabular}{|c|c|c|c|c|c|c|c|c|c|}
\hline \multirow{2}{*}{ No. } & \multirow{2}{*}{ Indicators } & \multicolumn{7}{|c|}{ Dose of lead, $\mathrm{mg} / \mathrm{kg}$} & \multirow{2}{*}{$\operatorname{NDS}_{05}$} \\
\hline & & Background & +25 & +50 & +100 & +250 & +500 & +1000 & \\
\hline 1 & The number of plants per 1 sq. m., pcs. & 146 & 179 & 174 & 150 & 145 & 169 & 157 & 23 \\
\hline 2 & Plant height, $\mathrm{cm}$ & 48,7 & 53,6 & 49,6 & 52,6 & 50,2 & 49,8 & 49,5 & 7,3 \\
\hline 4 & The height of the spike without awns, cm & 5,62 & 5,98 & 5,72 & 6,08 & 5,42 & 5,65 & 5,30 & 0,82 \\
\hline 5 & Culm height , $\mathrm{cm}$ & 40,1 & 43,2 & 41,2 & 42,0 & 41,8 & 41,3 & 41,8 & 6,0 \\
\hline 6 & The height of the spike awn, $\mathrm{cm}$ & 4,30 & 4,30 & 4,30 & 4,30 & 4,30 & 4,30 & 4,30 & 0,62 \\
\hline 7 & The total biomass (With spike), gr. & 355 & 228 & 255 & 193 & 189 & 203 & 197 & 34 \\
\hline 8 & Straw weight, gr. & 158 & 105 & 138 & 100 & 113 & 129 & 138 & 18 \\
\hline 9 & The number of grains per spike, pieces. & 26,2 & 25,5 & 28,2 & 23,6 & 22,5 & 19,3 & 20,2 & 3,4 \\
\hline 10 & Weight of 100 grains, gr. & 6,27 & 5,40 & 5,18 & 5,23 & 4,93 & 4,90 & 4,33 & 0,75 \\
\hline 11 & The weight of all grains per 1 sq. m., gr. & 197 & 124 & 117 & 95 & 76 & 75 & 58 & 15 \\
\hline 12 & The ratio of grain / straw & 1,40 & 1,19 & 0,84 & 0,93 & 0,72 & 0,59 & 0,43 & 0,13 \\
\hline 13 & Productivity, hundreds kg / ha & 19,7 & 12,3 & 11,7 & 9,5 & 7,6 & 7,5 & 5,8 & 1,5 \\
\hline 14 & Harvest at standard humidity, hundreds $\mathrm{kg} / \mathrm{ha}$ & 19,2 & 12,0 & 11,4 & 9,3 & 7,4 & 7,3 & 5,7 & 1,5 \\
\hline
\end{tabular}

The results confirmed the pattern that the generative plant organs are adversely affected by the pollutants to a greater extent than vegetative $[2,3,6]$.

Notably, the vegetative organs of winter wheat were productively developed, despite the high content of lead in them (see Table 2).

The present study showed that winter wheat received about $1 \%$ of the soil lead at a concentration of lead in the soil up to $500 \mathrm{mg} / \mathrm{kg}$ from the background, and more than $2 \%$ - at a concentration of $1000 \mathrm{mg} / \mathrm{kg}$ of soil (see Table 2). This is considerably more than $0.003-0.005 \%$ according to the data [5]. And it is despite the fact that the lead oxide is a compound practically insoluble in water, and chernozems are soils with high absorbency.

Lead pollution leads to its accumulation in winter wheat (see Table 2). The correlation coefficient of the lead content in wheat straw to its amount in chernozem was 0.95 , while in the grain it was 1.00 .

Table 2: The lead content in winter wheat grown on the contaminated chernozem (Botanical Garden of SFU)

\begin{tabular}{|c|c|c|c|c|c|c|c|c|}
\hline \multirow{2}{*}{ Product } & \multicolumn{7}{|c|}{ Dose of lead, $\mathrm{mg} / \mathrm{kg}$} & \multirow{2}{*}{ NDS $_{05}$} \\
\cline { 2 - 8 } & $\begin{array}{c}\text { Back } \\
\text { ground }\end{array}$ & +25 & +50 & +100 & +250 & +500 & +1000 & \\
\hline Straw & 0,13 & 0,31 & 0,54 & 1,32 & 2,03 & 4,27 & 22,00 & 0,23 \\
\hline Grain & 0,0016 & 0,005 & 0,03 & 0,06 & 0,10 & 0,22 & 0,47 & 0,011 \\
\hline
\end{tabular}

Interestingly, in the lead-contaminated soil by 1, 3-4, 4 times more lead starts to flow from the vegetative organs into grain than in uncontaminated soil (see Table 3).

Table 3: The coefficient of lead accumulation in winter wheat against the background

\begin{tabular}{|c|c|c|c|c|c|c|c|}
\hline & \multicolumn{7}{|c|}{ Dose of lead, mg / kg } \\
\cline { 2 - 8 } & $\begin{array}{c}\text { Back } \\
\text { ground }\end{array}$ & +25 & +50 & +100 & +250 & +500 & +1000 \\
\hline $\mathrm{C}_{\text {straw }}$ & 1,00 & 2,48 & 4,30 & 10,54 & 16,26 & 34,13 & 176,00 \\
\hline $\mathrm{C}_{\text {grain }}$ & 1,00 & 3,13 & 18,75 & 37,50 & 62,50 & 137,50 & 293,75 \\
\hline $\mathrm{C}_{\text {grain } /} \mathrm{C}_{\text {straw }}$ & - & 1,3 & 4,4 & 3,6 & 3,8 & 4,0 & 1,7 \\
\hline
\end{tabular}

The accumulation of lead in straw and in grain occurs already at its introduction into the soil in the amount of $+25 \mathrm{mg} / \mathrm{kg}$ (see Table 2). Accordingly, despite the strong development characteristics of the vegetative mass of wheat, neither grain nor straw should be used for food or forage purposes

Unlike lead pollution, oil even in minimal doses, had a significant impact on both the generative or vegetative parts of plants (see Table 4). Generative organs were also affected to a greater extent than vegetative ones. Content of oil in the chernozem even in the amount of $0.25 \%$ led to a deterioration in growth and development of winter wheat, and introduction into the soil of $10 \%$ of oil completely prevented the development of plants.

Table 4: Influence of contamination of ordinary chernozem with oil on the growth and development of winter wheat (Botanical Garden of SFU)

\begin{tabular}{|c|c|c|c|c|c|c|c|c|c|}
\hline \multirow[t]{2}{*}{ No. } & \multirow[t]{2}{*}{ Indicators } & \multicolumn{7}{|c|}{ The dose of the oil, $\mathrm{mg} / \mathrm{kg}$} & \multirow[t]{2}{*}{$\mathrm{NDS}_{05}$} \\
\hline & & Background & 0,25 & 0,5 & 1,0 & 2,5 & 5 & 10 & \\
\hline 1 & The number of plants per 1 sq. m., pcs. & 237 & 181 & 180 & 159 & 142 & 53 & 0 & 20 \\
\hline 2 & Plant height, $\mathrm{cm}$ & 54,6 & 59,3 & 51,8 & 58,3 & 54,8 & 54,4 & 0,0 & 6,9 \\
\hline 4 & The height of the spike without awns, cm & 6,65 & 6,30 & 6,68 & 6,23 & 6,00 & 5,35 & 0,00 & 0,77 \\
\hline 5 & Culm height, $\mathrm{cm}$ & 47,5 & 48,0 & 43,1 & 47,6 & 40,5 & 36,1 & 0,0 & 5,4 \\
\hline 6 & The height of the spike awn, cm & 5,00 & 4,79 & 4,29 & 4,47 & 3,47 & 2,67 & 0,00 & 0,51 \\
\hline 7 & The total biomass (with spike), gr. & 345 & 263 & 308 & 265 & 265 & 55 & 0 & 31 \\
\hline 8 & Straw weight, gr. & 179 & 146 & 166 & 159 & 159 & 40 & 0 & 18 \\
\hline 9 & The number of grains per spike, pieces. & 34,1 & 28,2 & 24,8 & 26,6 & 20,2 & 12,1 & 0,0 & 3,0 \\
\hline 10 & Weight of 100 grains, gr. & 8,00 & 4,97 & 4,97 & 5,37 & 5,37 & 4,20 & 0,00 & 0,68 \\
\hline 11 & The weight of all grains per 1 sq. m., gr. & 220 & 128 & 133 & 106 & 100 & 15 & 0 & 15 \\
\hline 12 & The ratio of grain / straw & 1,09 & 0,88 & 0,80 & 0,68 & 0,63 & 0,38 & 0,00 & 0,09 \\
\hline 13 & Productivity, hundreds $\mathrm{kg} / \mathrm{ha}$ & 22,0 & 12,8 & 13,3 & 10,6 & 9,0 & 1,5 & 0,0 & 1,4 \\
\hline 14 & Harvest at standard humidity, hundreds $\mathrm{kg} / \mathrm{ha}$ & 21,5 & 12,5 & 13,0 & 10,3 & 8,8 & 1,5 & 0,0 & 1,4 \\
\hline
\end{tabular}

The study confirmed the pattern that the generative organs of plants are exposed to the adverse effects of pollutants to a greater extent than the vegetative ones.

Excessive lead content in ordinary chernozem in the amount of 25 $\mathrm{mg} / \mathrm{kg}$, and the oil content of $0.25 \%$ of soil weight, cannot be considered environmentally safe (allowable), because they cause significant disruption of plant growth and development, and lead, besides, enters grain and straw in large quantities.

\section{Findings}

1. Generative organs of plants have been negatively affected with lead and oil to a greater degree than vegetative ones. Contamination of soil, even with significant amounts of lead (background $+1000 \mathrm{mg} / \mathrm{kg}$ ) had virtually no impact on the morphological indicators of vegetative organs of winter wheat, whereas the indicators of the generative organs, including productivity, reduced their value down to 3 times. Oil even in minimal doses had a significant influence on the generative and 
vegetative organs of plants. The content of oil in the chernozem in the amount of $10 \%$ completely prevented the development of winter wheat.

2. Lead pollution of the soil leads to its accumulation in the winter wheat. Winter wheat received about $1 \%$ of the soil lead at a concentration of lead in the soil between the background and 500 $\mathrm{mg} / \mathrm{kg}$, and more than $2 \%$ - at a concentration of $1000 \mathrm{mg} / \mathrm{kg}$ of the soil. The correlation coefficient of the lead content in the wheat straw with its amount in the chernozem was 0,95 , while in the grain it was 1,00 . The lead penetration from the vegetative organs into the grain increases 1,3-4,4 times in the leadcontaminated soil.

3. Excessive lead content in ordinary chernozem in the amount of $25 \mathrm{mg} / \mathrm{kg}$, and the oil content of $0.25 \%$ of soil weight, cannot be considered environmentally safe (allowable), because they cause significant disruption of plant growth and development, and lead, besides, enters grain and straw in large quantities.

\section{Acknowledgements}

The work was supported in part by the Ministry of Education and Science of the Russian Federation (5.5735.2017/8.9) and the State Program for Leading Scientific Schools of the Russian Federation (NSh-3464.2018.11).

\section{References}

[1] Y.V. Alekseev, Heavy metals in soils and plants, Moscow, Agropromizdat, 1987.

[2] V.A. Bol'shakov, Contamination of soil and vegetation with heavy metals, Publishing House VNIITEISKH, Moscow, 1978.

[3] V.B. Ilyin, A.I. Syso, Microelements and heavy metals in soils and plants, Publishing house SB RAS, Novosibirsk, 2001.

[4] A. Kabata-Pendias, H. Pendias, Microelements in soils and plants, Mir, Moscow, 1989

[5] N.A. Kireeva, H.A. Yumaguzina, G.G. Kuzyahmetov, Growth and development of oat plants in oil-contaminated soils, the Agricultural Biology 5 (1996) 48-54.

[6] S.I. Kolesnikov, K.S. Kazeev, V.F. Valkov, Ecological state and function of the soil under the conditions of chemical pollution, Rostizdat publ. house, Rostov-on-Don, 2006.

[7] F.H. Khaziev, E.I. Tishkina, N.A. Kireeva, et al., Influence of oil pollution on some components of the agro-ecosystem, Agrochimia 2 (1988) 56-61.

[8] M.S. Malinina, D.S. Orlov, G.V. Motuzova, at al., Chemical contamination of soils and their protection, Agropromizdat, Moscow, 1991.

[9] V.S. Gorbatov, Stability and transformation of heavy metal oxides of metals ( $\mathrm{Zn}, \mathrm{Pb}, \mathrm{Cd})$ in the soils, Pochvovedenie 1 (1988) 35-43.

[10] B.A. Dospekhov, Methods of field experience, Kolos, Moscow, 1979. 